\title{
Rheological Properties of Individual Triticale Flour Streams
}

\author{
Roman Khazhsetovich Kandrokov* \\ Federal State Budgetary Educational Institution of Higher Education, Russia \\ *Corresponding author: Roman Khazhsetovich Kandrokov, Federal State Budgetary Educational Institution of Higher \\ Education, Volokolamskoe highway, House 11, 125080, Moscow, Russia
}

\section{ARTICLE INFO}

Received: May 07, 2021

Published: 幽 May 14, 2021

Citation: Roman Khazhsetovich Kandrokov. Rheological Properties of Individual Triticale Flour Streams. Biomed J Sci \& Tech Res 35(5)-2021. BJSTR. MS.ID.005757.

\begin{abstract}
For the first time, the differences in rheological properties of triticale flour from various technological systems were investigated using the mixolab system (Chopin Technologies, France). An increase in water absorption capacity (WTS), a decrease in the stability time during dough kneading with an increase in the number of peripheral parts of the caryopsis, a change in the value of the viscosity index, which increases from the first to the third broken system, has been established and decreases from 1st to 6th grinding system. It has been revealed that the highest value of the IPC index has flour from the 6th grinding system, which contains the largest number of peripheral parts of the caryopsis, which provides a high-water absorption capacity in comparison with other flows. The viscosity in these samples of triticale flour depends not only on the activity of amylases, but also on the state of starch, its quality characteristics, as well as the presence of peripheral parts containing non-starch polysaccharides. The amylase index indirectly characterizes the amylolytic activity of flour. A high amylase index indicates a weak $\alpha$-amylase activity in all studied flour streams. The starch retrogradation index is related to the ability of the finished product to resist staling. A high value of this indicator characterizes a faster staling of bread made from triticale flour.
\end{abstract}

\section{Introduction}

The use of processed products of unconventional grain crops, such as triticale, in various sectors of the food and processing industry is currently attracting more and more attention from both researchers and manufacturers in the Russian Federation. This is due to the increase in acreage, the creation of new varieties of triticale grain, numerous studies of the technological, biochemical and biological potential of triticale grain [1-7]. Triticale is a unique grain crop, created by man by hybridization of wheat and rye, and has high nutritional values, often surpassing those of both parental forms [1]. Currently, in the Russian Federation, triticale grain is used mainly as a grain component of compound feed and a small part to produce alcohol. It is promising to use triticale flour as a raw material, instead of wheat bakery flour, in the production of flour confectionery products: cookies, biscuits, biscuits, waffles, muffins, crackers, etc. Triticale flour can be used in the production of noodles that do not require boiling, quick breakfasts, or for the manufacture of dietary and therapeutic and prophylactic types of bread, including whole grain and multi-grain [8-14]. In addition, the triticale grits can be used to produce mass-market pasta. The actual direction of scientific research is the technology of processing triticale grain into starch [15]. Another direction is the use of triticale bran to produce dietary fiber $[16,17]$ and biomodified products of grain processing of triticale $[18,19]$. It should be noted that there is currently no industrial production of high-quality triticale flour at existing flour mills in the Russian Federation.

Studies by foreign scientists conducted over the past ten years are mainly related to the biology of triticale species and biosafety during its growth and development, the origin of hexaploid triticale, industrial production of triticale and its competitiveness with wheat, genomics and biotechnology of triticale grain and its processing products [20-28]. Until recently, triticale grain, in terms of its technological properties, was mainly considered as an analogue of rye grain [13]. But the work of Russian breeders and scientists of related specialties made it possible to develop 
and introduce into agricultural practice new promising varieties of triticale with a predominance of the wheat genotype, which is reflected in the phenotypic traits of triticale grain, namely, on the size characteristics, the shape of the weevil (the sphericity coefficient is more than 0.8), color, structural, mechanical and technological properties [1].

Studies of triticale grain and products of its processing, carried out in recent years at VNIIZ, a branch of the Federal Research Center of Food Systems named after V.M. Gorbatov" RAS, allowed to gain new knowledge about the technological properties, biochemical composition and varietal characteristics of triticale grain and products of its processing. Based on the results of the research, new technologies have been developed for obtaining various varieties of triticale flour, whole and numbered cereals with a certain composition and properties that will be in demand in bakery, pasta, confectionery, starch, meat and other food industries $[2,3,5,7,28]$. The aim of the work is to determine the rheological and baking properties of individual streams and formed varieties of triticale bakery flour obtained according to developed and reduced technological schemes.

\section{Materials and Methods}

In experimental studies carried out in the departments of integrated grain processing and safety of grain and grain products VNIIZ - a branch of the Federal State Budgetary Scientific Institution "FNTS Food Systems named after V.M. Gorbatov "of the Russian Academy of Sciences and the Moscow State University of Food Production, we used the triticale grain variety" Saur "of the 2018 harvest, bred by the Donskoy Zonal Research Institute of Agriculture. The whiteness of triticale flour was determined by measuring the reflectivity of the compacted-smoothed flour surface using a photoelectric device, ash content - by burning flour and bran, followed by determining the mass of the fireproof residue, water absorption capacity and bran, followed by determining the mass of the fireproof residue, water absorption capacity and rheological properties - by measuring and registration of the consistency of the dough in the process of its formation from water and flour, the development of the dough and changes in its consistency in time during the kneading process using the Mixolab device (Chopin Technologies, France).

\section{Results and their Discussion}

At the first stage of research, varieties of triticale flour were formed from 3 streams of flour A, B and C [2]. Stream A is flour from the central part of the endosperm, obtained on 1-3 grinding systems +1 grinding system, according to a developed scheme, and flour, obtained from 1-3 grinding systems, according to a reduced processing scheme. Stream B is flour from the peripheral part of the endosperm and subaleuron layer, obtained on 3 and 4 grinding systems and on I-III torn systems. Stream B consists of fragments of endosperm and membranes from other technological systems.

At the second stage of the research, the rheological properties were assessed [28] of 10 separate streams of triticale flour from grain of the "Saur" variety, obtained according to a developed technological scheme using the mixolab system (Chopin Technologie, France), in the Chopin + protocol, which involves 5 research phases : I lasts 8 minutes at $30^{\circ} \mathrm{C}$; II - 15 minutes with a sequential increase in temperature at a rate of $4^{\circ} \mathrm{C}$ per minute from 30 to $90^{\circ} \mathrm{C}$; III $-8 \mathrm{~min}$ at $90^{\circ} \mathrm{C}$; IV -10 minutes, with a sequential decrease in temperature from 90 to $50^{\circ} \mathrm{C} ; \mathrm{V}-5 \mathrm{~min}$ at $50^{\circ} \mathrm{C}$. The torque at the analyzed points of the graph, from the point of view of biochemical processes, characterizes: C1 - dough formation; C2 - liquefaction of the dough, C3 - the maximum rate of starch gelatinization; C4, C5 - start and end of starch retrogradation within the framework of the experiment; $\alpha, \beta, \gamma$ - rates of biochemical reactions (calculated values). The following indicators were also analyzed: water absorption capacity of the test (WTS), \%; dough formation time, min; dough stability, min. The data of the integral assessment of the rheological properties of the test are visualized on the graph of the dependence of the torque $(\mathrm{N} \cdot \mathrm{m})$ on time (min) in a certain temperature mode (Tables $1 \& 2$ ) [27,28].

The viscosity value was different and amounted to 2 points for the I broken system, 7 points for the 1 grinding system and 5 points for the 4 th grinding system. It is worth noting that the viscosity depends both on the state of the starch and on the activity of amylases, as well as on the peripheral parts that contain nonstarchy polysaccharides. The amylase index depends on the amylolytic activity of the flour. The higher its value, the lower the enzyme activity. The "starch retrogradation index" is related to the rate of staling of the finished product. A high value of this indicator characterizes a faster rate of staling.

As can be seen from Table 1, the VPS of the flour flows increases from 1 grinding to 6 grinding systems, which is associated with the appearance of a larger number of peripheral water-absorbing particles in the flour. On torn systems from the first to the third, an increase in TTS is also observed. The flour obtained on the grinding system occupies an intermediate position between the torn and grinding systems and has a VPS of 55.0\%. During the first phase (C1), the flow stability is uneven, however, a tendency to decrease the stability time from the 1st to the 6th grinding system can be observed, which can also be associated with an increase in the content of peripheral particles and a decrease in the time of dough formation. At phase II (C2) of the mixolabogram curve, the lowest torque is noted, which is associated with the dilution of the dough and indirectly characterizes the state of the protein complex. The viscosity increases from I broken to III broken system. The lowest viscosity is observed on the grinding system. On grinding systems, an increase in torque is observed, and then its decrease, which, apparently, is associated with an increase in the proportion of peripheral fractions in the flour of these systems. 
Table 1: The main parameters of the phases of the rheological analysis of the test of individual streams of triticale flour from grain of the "Saur" variety.

\begin{tabular}{|c|c|c|c|c|c|c|c|}
\hline $\begin{array}{l}\text { Flour sample from the } \\
\text { technological system }\end{array}$ & Air Force, \% & Stability, min & C1 & C2 & C3 & C4 & C5 \\
\hline I torn system & 54,2 & 4,42 & 1,030 & 0,253 & 1,273 & 2,178 & 3,644 \\
\hline II torn system & 53,1 & 3,87 & 1,109 & 0,286 & 1,401 & 2,294 & 3,766 \\
\hline III torn system & 53,5 & 4,78 & 1,226 & 0,335 & 1,809 & 2,245 & 3,529 \\
\hline 1 grinding system & 55,0 & 5,23 & 0,992 & 0,299 & 2,031 & 2,438 & 3,859 \\
\hline 1 grinding system & 54,1 & 5,62 & 1,093 & 0,335 & 1,947 & 2,449 & 4,221 \\
\hline 2 grinding system & 55,0 & 5,72 & 1,159 & 0,367 & 2,035 & 2,490 & 4,150 \\
\hline 3 grinding system & 57,0 & 5,42 & 1,156 & 0,372 & 1,820 & 2,441 & 3,957 \\
\hline 4 grinding system & 57,6 & 5,65 & 1,081 & 0,337 & 1,752 & 2,258 & 3,489 \\
\hline 5 grinding system & 57,7 & 5,05 & 1,113 & 0,329 & 1,497 & 1,953 & 3,059 \\
\hline 6 grinding system & 58,3 & 4,62 & 1,236 & 0,354 & 1,875 & 1,826 & 2,731 \\
\hline
\end{tabular}

In the process of phase III (C3), the starch granules are destroyed and gelatinized, which leads to an increase in torque. A clear dependence of the increase in the moment of force on the granulometric composition of the flour on the torn system and its decrease on the grinding system is observed. During phase IV (C4), there is a gradual increase in the torque in the torn systems and its decrease in the last grinding systems. The highest torque is recorded on the $2^{\text {nd }}$ grinding system. Phase V (C5) characterizes the process of starch retrogradation during cooling and the rate of staling of finished flour products. Here, a decrease in torque on grinding systems is especially noticeable from $4.221 \mathrm{~N} \cdot \mathrm{m}$ at the 1 st grinding system to $2.731 \mathrm{~N} \cdot \mathrm{m}$ at the 6 th grinding system (Table 2). ${ }^{*} \alpha$ - characteristic of the reaction rate of liquefaction, expressed by the angle of inclination of the tangent to the mixolabogram from the moment the temperature reaches $30^{\circ} \mathrm{C}$ to the point $\mathrm{C} 2 ; \beta$ characteristic of the reaction rate of starch gelatinization, expressed by the angle of inclination of the tangent to the mixolabogram in the section C2 - C3; $\gamma$ - characteristic of the rate of amylolysis, expressed by the angle of inclination of the tangent to the mixolabogram in the section C3 - C4.

Table 2: Calculated values of the reaction rates * for individual streams of triticale flour from grain of the "Saur" variety.

\begin{tabular}{|c|c|c|c|c|c|}
\hline $\begin{array}{c}\text { Flour sample from the } \\
\text { technological system }\end{array}$ & $\boldsymbol{\alpha} \mathbf{N} \cdot \mathbf{m} / \mathbf{m i n}$ & $\boldsymbol{\beta , N} \cdot \mathbf{m} / \mathbf{m i n}$ & $\boldsymbol{\gamma}, \mathbf{N} \cdot \mathbf{m} / \mathbf{m i n}$ & Torque, $\mathbf{N} \cdot \mathbf{m} / \mathbf{m i n}$ & $\begin{array}{c}\text { Amplitude, } \mathbf{N} \cdot \mathbf{m} / \\
\mathbf{m i n}\end{array}$ \\
\hline I torn system & $-0,036$ & 0,130 & 0,088 & 3,644 & 0,134 \\
\hline II torn system & $-0,056$ & 0,160 & 0,078 & 3,766 & 0,141 \\
\hline III tattered system & $-0,064$ & 0,374 & 0,010 & 3,529 & 0,140 \\
\hline 1 grinding system & $-0,056$ & 0,322 & 0,032 & 3,859 & 0,103 \\
\hline 1 grinding system & $-0,060$ & 0,286 & 0,038 & 4,221 & 0,108 \\
\hline 2 grinding system & $-0,062$ & 0,416 & 0,042 & 3,957 & 0,141 \\
\hline 3 grinding system & $-0,056$ & 0,292 & 0,020 & 0,168 \\
\hline 4 grinding system & $-0,058$ & 0,316 & 0,020 & 3,489 & 0,073 \\
\hline 5 grinding system & $-0,052$ & 0,206 & 0,028 & 3,059 & 0,097 \\
\hline 6 grinding system & $-0,060$ & 0,388 & 0,022 & 2,731 \\
\hline
\end{tabular}

Table 3 presents the rheological characteristics of individual streams of triticale flour in the form of six consecutive indices: water absorption capacity index (WTS), dough mixing index, gluten index, viscosity index, amylase index, starch retrogradation index. The analysis of the profile indices (Table 3) shows that the highest value of the IPC index has flour from the 6th grinding system, which contains the largest number of peripheral parts of the caryopsis, which provides a high-water absorption capacity in comparison with other flows. The kneading index is associated with the stability of the dough during kneading, which is 4.42 minutes for the first break ( 1 point), 5.62 minutes for 1 grinding ( 2 points) and 5.65 minutes for the 4 th grinding system ( 2 points), respectively. The gluten index characterizes the stability of protein molecules during heating of the dough in the range from $30^{\circ} \mathrm{C}$ to $60^{\circ} \mathrm{C}$. 
Table 3: Indices of mixolab profiles of triticale flour flows from Saur grain.

\begin{tabular}{|c|c|c|c|c|c|c|}
\hline \multirow{2}{*}{$\begin{array}{l}\text { Flour sample from the } \\
\text { technological system }\end{array}$} & \multicolumn{6}{|c|}{ Mixolab profile indices } \\
\hline & UPU index & Kneading Index & Gluten Index & Viscosity Index & Amylase index & $\begin{array}{l}\text { Index Starch } \\
\text { retrogradation }\end{array}$ \\
\hline I torn system & 1 & 1 & 5 & 2 & 9 & 8 \\
\hline II torn system & 1 & 0 & 5 & 3 & 9 & 8 \\
\hline III torn system & 1 & 2 & 2 & 6 & 8 & 8 \\
\hline 1 grinding system & 2 & 1 & 5 & 8 & 8 & 8 \\
\hline 1 grinding system & 1 & 2 & 4 & 7 & 9 & 8 \\
\hline 2 grinding system & 2 & 2 & 3 & 8 & 9 & 8 \\
\hline 3 grinding system & 3 & 2 & 3 & 6 & 9 & 8 \\
\hline 4 grinding system & 4 & 2 & 4 & 5 & 9 & 8 \\
\hline 5 grinding system & 4 & 2 & 4 & 3 & 8 & 7 \\
\hline 6 grinding system & 5 & 2 & 3 & 3 & 8 & 7 \\
\hline
\end{tabular}

Interpretation of the gluten index presents a certain difficulty, since during the heating of the dough in this temperature range, two very important phenomena occur: the starch granules begin to swell, but their structure remains unchanged, while the action of $\alpha$-amylase, if any, is quite insignificant. The change in the consistency of the dough is largely associated with changes in the structure of gluten proteins with the rupture of hydrogen bonds or better stability of proteins, which is also associated with their spatial structure, and, ultimately, with the nature of these protein complexes [28]. In the formation of the quality of gluten, its elasticelastic properties, the decisive role is played by the fractions of gluten proteins - gliadin and glutenin. However, it is necessary to consider the role of other compounds that interact with gluten proteins and affect the structure and properties of gluten, namely lipids, carbohydrates, enzymes (proteases and their protein inhibitors, amylases, lipoxygenase) [28].

The value of the viscosity index was 2 points for flour with I torn system, 7 points for flour with 1 grinding system and 5 points for flour from 4 grinding system. This indicator characterizes the phase at which the largest number of physicochemical and biochemical parameters interact. It is worth noting that the viscosity in these samples depends not only on the activity of amylases, but also on the state of starch, its quality characteristics, as well as the presence of peripheral parts containing non-starch polysaccharides.

The amylase index indirectly characterizes the amylolytic activity of flour. A high amylase index indicates a weak $\alpha$-amylase activity in all studied flour streams. The starch retrogradation index is related to the ability of the finished product to resist staling. A high value of this indicator characterizes a faster staling rate.

\section{Conclusions}

a) The rheological properties of triticale flour from various technological systems (streams) clearly demonstrate a natural increase in the TPS, a decrease in the stability time when kneading the dough as the number of peripheral parts of the caryopsis increases.

b) The influence of the state of the protein-proteinase and carbohydrate-amylase complexes of individual flour streams, along with the influence of other factors, including the presence of nonstarch polysaccharides from the peripheral parts of the caryopsis, is manifested to a greater extent in the change in the value of the viscosity index, which increases from I to III of the torn system, and decreases from the 1 st to the 6 th grinding system.

c) The viscosity in these samples of triticale flour depends not only on the activity of amylases, but also on the state of starch, its quality characteristics, as well as the presence of peripheral parts containing non-starch polysaccharides. The amylase index indirectly characterizes the amylolytic activity of flour.

d) A high amylase index indicates a weak $\alpha$-amylase activity in all studied flour streams. The starch retrogradation index is related to the ability of the finished product to resist staling. A high value of this indicator characterizes a faster rate of staling.

\section{References}

1. Sokol NV (2014) Triticale is a grain culture. Palmarium Academic Pulishing pp. 143.

2. Pankratov GN, Meleshkina EP, Kandrokov RKh, Vitol IS (2016) Technological properties of new varieties of triticale flour. Khleboprodukty 1: 60-62.

3. Vitol IS, Karpilenko GP, Kandrokov RKh, Starichenkov AA, Koval AI, et al. (2015) Protein-proteinase complex of triticale grain. Storage and processing of agricultural raw materials 8: 36-38.

4. Vitol IS, Meleshkina EP, Kandrokov RKh, Verezhnikova IA, Karpilenko GP (2016) Biochemical characteristics of new varieties of triticale flour. Khleboprodukty 2: 42-43.

5. Magomedov GO, Malyutina TN, Shapkarina AI (2016) Development of technology for whipped flour confectionery products of increased nutritional value using triticale flour. Vestnik VSUIT 1: 106-109. 
6. Karchevskaya OV, Dremucheva GF, Grabovets AI (2013) Scientific foundations and technological aspects of the use of triticale grain in the production of bakery products. Bread-making of Russia 5: 28-29.

7. Woś H, Brzeiński W, Woś J (2013) Breadmaking quality Triticale bred in Poland. 8th International Triticale Symposium, Ghent, Belgium pp. 23.

8. Koryachkina SYa, Kuznetsova EA, Cherepnina LV (2011) Technology of whole grain triticale bread. Orel: GU-UNPK pp. 116.

9. Grabovets AI, Krokhmal AV, Dremucheva GF, Karchevskaya OE (2013) Breeding of triticale for baking purposes. Russ. Agric. Sci 39: 197-202.

10. Rakha A, Aman P, Andersson R (2013) Rheological characterization of aqueous extracts of triti-cale grains and its relation to dietary fiber characteristics. J Cereal Sci 57(2): 230-236.

11. Rakha A, Aman P, Andersson R (2013) Rheological characterization of aqueous extracts of triticale grains and its relation to dietary fiber characteristics. J. Cereal Sci 57: 230-236.

12. Meleshkina EP, Pankratov GN, Vitol IS, Kandrokov RH, Tulyakov DG (2017) Innovative Trends in the Development of Advanced Triticale Grain Processing Technology. Foods and Raw Materials 5(2): 70-82.

13. Pankratov GN, Meleshkina EP, Vitol IS, Kandrokov RKh (2017) Actual directions of technological development of the milling branch of the food industry. Food industry 8: 44-49.

14. Barnett RD, Blount AR, Pfahler PL, Bruckner PL, Wesenberg DM, et al. (2006) Envi-ronmental stability and heritability estimates for grain yield and test weight in triticale. J Appl Genet 47: 207-213.

15. Blum A (2014) The abiotic stress response and adaptation of triticale - a review. Cereal Res. Com-mun 42(3): 359-375.

16. De Laethauwer S, Reheul D, De Riek J, Haesaert G (2012) Vp1 expression profiles during kernel de-velopment in six genotypes of wheat, triticale and rye. Euphytica 188: 61-70.

17. Dennett AL, Cooper KV, Trethowan RM (2013) The genotypic and phenotypic interaction of wheat and rye storage proteins in primary triticale. Euphytica 194: 235-242.

18. Manley M, McGoverin C, Snyders F, Muller N, Botes W, et al. (2013) Prediction of triticale grain quality properties, based on both chemical and indirectly measured reference methods using near-infrared spectroscopy. Cereal Chem 90(6): 540-545.

19. McGoverin C, Snyders F, Muller N, Botes W, Fox G, et al. (2011) A review of triticale uses and the effect of growth environment on grain quality. J. Sci. FoodAgric 91(7): 1155-1165.

20. He ML, McAllister TA, Hernandez-Calva LM, Aalhus JL, Dugan MER, et al (2014) Effect of dietary inclusion of triticale dried distillers' grain and oilseeds on quality and fatty acid profile of meat from feedlot steers. Meat Sci 97(1): 76-82

21. Ukalska J, Kociuba W (2013) Phenotypical diversity of winter triticale genotypes collected in the Polish gene bank between 1982 and 2008 with regard to major quantitative traits. Field-CropsRes 149: 203-212.

22. Bona L, Acs E, Lantos C, Purnhauser L, Lango B, Tomoskozi S (2013) Human utilization of tritica-le: technological and features, milling and baking experiments. In: Abstracts 8th international trit-icale symposium. Ghent, Belgium pp. 46.

23. (2009) Guide to Mixolab Applications. Rheological and enzymatic analysis (Ma-nueld'applications Mixolab) 28: 79.

24.(2008) ICC No. 173. Whole meal and flour from T. aestivum Determination of rheological behavior as a function of mixing and temperature increase, ICC, Standard. Vienna.

25. Antanas S, Alexa E, Negrea M, Guran A, Lazureanu E (2013) Studies regarding rheological proper-ties of triticale, wheat and rye flours. J. of Horticulture, Forestry and Biotechnology 17(1): 345-349.

26. Tulyakov DG, Meleshkina EP, Vitol IS, Pankratov GN, Kandrokov RKh (2017) Evaluation of the properties of flour from triticale grain using the Mixolab system. Storage and processing of agricultural raw materials 1: 20-23.

27. Dubat A Le mixolab (2009) Profiler: un outilcomplet pour le controlequalite des bles et des farines. In-dustries des Cereales 161: 1126.

28. Dubtsova GN, Nechaev AP, Molchanov MI (2000) Molecular biological aspects of the formation of lipid-protein complexes and assessment of their role in the structure of gluten. In the book: Vegetable protein: new perspectives. Moscow: Pishchepromizdat pp. 100-121.

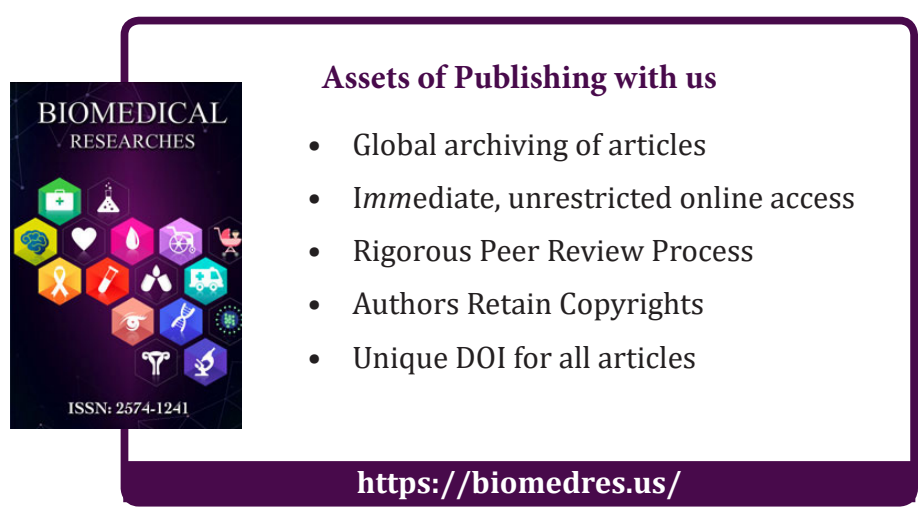

